\title{
X-Ray Tube
}

National Cancer Institute

\section{Source}

National Cancer Institute. X-Ray Tube. NCI Thesaurus. Code C48435.

A vacuum tube containing a metal target onto which a beam of electrons is directed at high energy for the generation of $\mathrm{X}$ rays. 